\title{
Evaluation of rootstocks for Valencia and Navel orange trees in Saudi Arabia
}

Mongi ZeKRI ${ }^{a *}$, Ali AL-JALEeL ${ }^{b}$

a University of Florida, IFAS, Hendry County Extension Office, PO Box 68, LaBelle, Florida 33975, USA maz@mail.ifas.ufl.edu

b Najran Horticulture Development Research Center, Ministry of Agriculture, Food \& Agriculture Organization, Najran, Kingdom of Saudi Arabia
${ }^{*}$ Correspondence and reprints

Received 15 May 2003 Accepted 4 August 2003

Fruits, 2004, vol. 59, p. 91-100 (C) 2004 Cirad/EDP Sciences All rights reserved

DOI: 10.1051/fruits:2004009

RESUMEN EsPAÑOL, p. 100

\section{Evaluation of rootstocks for Valencia and Navel orange trees in Saudi Arabia.}

Abstract - Introduction. Environmental conditions and cultural practices vary considerably from one region to another. Therefore, a long-term study was carried out to investigate the horticultural adaptability and performance of 'Olinda Valencia' and 'Parent Washington Navel' orange trees on nine commercial rootstocks in the Najran area of Saudi Arabia. Materials and methods. The trees were planted in 1987 with a $(6.0 \times 6.0) \mathrm{m}$ spacing and a density of 278 trees $h^{-1}$. Fruit yield, fruit size, individual fruit weight, peel thickness, percent of juice, soluble solids and acid were measured. Results. Over the 7-year production period, trees on Volkamer lemon (VL), Citrus macrophylla $(\mathrm{Cm})$ and rough lemon (RL) were the most productive and trees on Cleopatra mandarin (Cleo) and Swingle citrumelo $(\mathrm{Sc})$ were the least productive. Trees on Sour orange (SO), Amblycarpa, Carrizo citrange (CC) and C. taiwanica (Ct) were intermediate in fruit production. The greatest fruit individual weight and largest fruit were found on trees budded on RL, VL and $\mathrm{Cm}$, while the lowest fruit weight and smallest fruit were found on trees budded on Cleo and SO. Trees on RL had the lowest juice content. Fruit from trees on CC and SO accumulated the highest soluble solids and fruit from trees on $\mathrm{Cm}$ and $\mathrm{Ct}$ accumulated the lowest soluble solids. Valencia trees produced more fruit with higher juice content and soluble solids than Navel trees. Conclusion. Overall, trees on Swingle citrumelo and Cleopatra mandarin performed most poorly. Trees on vigorous rootstocks (Volkamer lemon, C. macrophylla, rough lemon) performed better and were more productive than trees on other rootstocks and Valencia trees were more profitable than Navel trees.

Saudi Arabia / Citrus sinensis / rootstocks / crop performance / variety trials

\section{Évaluation de porte-greffes pour des orangers Valencia et Navel en Arabie Saoudite.}

Résumé - Introduction. Les conditions environnementales et les pratiques culturales varient considérablement d'une région à l'autre. C'est pourquoi, une étude à long terme a été effectuée pour étudier l'adaptabilité et les performances horticoles d'orangers de type Washington Navel et Valencia Olinda sur neuf porte-greffes commerciaux dans la région de Najran en Arabie Saoudite. Matériel et méthodes. Les arbres ont été plantés en 1987 à $(6,0$ × $6,0) \mathrm{m}$ d'intervalle et une densité de 278 arbres $\cdot \mathrm{ha}^{-1}$. Le rendement en fruits, la dimension et le poids individuel du fruit, l'épaisseur de peau, le taux de jus, l'extrait sec et l'acidité ont été mesurés. Résultats. À l'issue d'une période de 7 ans de production, les arbres greffés sur Citrus volkameriana (VL), C. macrophylla $(\mathrm{Cm})$ et Rough lemon (RL) ont été les plus productifs et ceux greffés sur mandarine Cleopatra (Cleo) et citrumelo Swingle (Sc) ont été les moins productifs. Les arbres greffés sur orange amère (SO), Amblycarpa, citrange Carrizo (CC) et C. taiwanica $(C t)$ ont présenté une production intermédiaire. Le plus grand poids individuel de fruit et les plus grands fruits ont été trouvés sur des arbres greffés sur RL, VL ou $\mathrm{Cm}$, alors que le poids de fruit le plus faible et les fruits les plus petits ont été trouvés sur des arbres greffés sur Cleo et SO. Les orangers greffés sur RL ont eu les plus faibles teneurs en jus. Les fruits portés par les arbres greffés sur CC et SO ont accumulé les plus forts taux de solides solubles et les fruits sur $\mathrm{Cm}$ et $\mathrm{Ct}$ ont en présenté les plus bas. Les orangers Valencia ont produit plus de fruits avec plus de jus et de solides solubles que les orangers Navel. Conclusion. D'une façon générale, les arbres sur citrumelo Swingle et mandarine Cleopatra ont été les moins productifs. Les arbres sur porte-greffes vigoureux (C. volkameriana, C. macrophylla, rough lemon) ont présenté de meilleures performances et ont été plus productifs que les orangers greffés sur d'autres porte-greffes; les orangers Valencia ont été plus intéressants que les Navels.

Arabie saoudite / Citrus sinensis / porte-greffe / essai de variété / performance de culture 


\section{Introduction}

Citrus acreage in the Kingdom of Saudi Arabia is over 15000 ha. The Najran area (lat $17^{\circ} 5^{\prime} \mathrm{N}$, long $44^{\circ} 13^{\prime} \mathrm{W}$, alt 800-1000 m), located between the Azir Mountains and the Rhub Al-Khali Desert (Empty Quarters) in Southwest Saudi Arabia, has 25\% of the total citrus acreage. The climate in Najran is hot, arid and subtropical with an average yearly rainfall of $60 \mathrm{~mm}$ falling mainly during the winter, which is relatively mild. That area, with over 1 million trees and over 1000 citrus orchards, has mean maximum and minimum temperatures of $23-36{ }^{\circ} \mathrm{C}$ and 6 $20{ }^{\circ} \mathrm{C}$, respectively. Orchard size ranges from ( 1 to 50 ) ha. In the Kingdom of Saudi Arabia, fruit is not sold based on soluble solids. All fruit is marketed fresh by weight and consumed locally [1].

'Clementine' mandarin and 'Parent Washington Navel' orange are among the most popular citrus cultivars grown in the Najran area. Fifteen years ago, the most popular rootstocks in the area were sour orange, 'Troyer' and 'Carrizo'. Because of increasing problems with high $\mathrm{pH}$ and salinity, rootstocks have become a more critical issue than in previous years. 'Volkamer' lemon, Citrus macrophylla and 'Cleopatra' mandarin have been gaining ground and are becoming very popular [2].

Rootstocks have had a substantial role in the development of the citrus industry in the world. The effect of rootstocks on citrus fruit production and fruit quality has been intensively studied in many citrus-producing areas [3-25]. Findings from these studies have revealed different results and inconsistent conclusions, which were attributed to several factors including climatic conditions and soil characteristics. Therefore, it is unwise to adopt rootstock recommendations from one part of the world to another without a thorough evaluation locally. Since environmental conditions and cultural practices are unique and vary considerably from one area to another, a long-term study was carried out to determine the horticultural adaptability and performance of 'Olinda Valencia' and 'Parent Washington Navel' orange [Citrus sinensis (L.) Osbeck] trees on nine commercial rootstocks grown on a typical soil where the Saudi Arabian citrus industry is flourishing. On-site field evaluation of rootstocks benefits local growers in selecting the most suitable rootstocks for their citrus cultivars under their specific climatic and edaphic conditions.

\section{Materials and methods}

The experiment was conducted in Najran, Saudi Arabia, to compare the effects of sour orange (Citrus aurantium L.), 'Carrizo' citrange [Citrus sinensis (L.) Osbeck $\times$ Poncirus trifoliata (L.) Raf.], 'Cleopatra' mandarin (Citrus reshni Hort. ex Tan.), rough lemon (Citrus limon), 'Swingle' citrumelo [(Citrus paradisi (L.) $\times$ Poncirus trifoliata (L.) Raf.], Taiwanica (Citrus Taiwanica), Amblycarpa (Citrus limonellus var. Amblycarpa Hassk), 'Volkamer' lemon (Citrus volkameriana Ten and Pasq.), and Macrophylla (Alemow) (Citrus macrophylla Wester) on different fruit characteristics of 'Olinda Valencia' and 'Parent Washington Navel' orange trees. The budwood source and budded trees were free of viruses and viroids. The trees were planted in 1987 with a $(6.0 \times 6.0) \mathrm{m}$ spacing and a density of 278 trees $\cdot \mathrm{ha}^{-1}$.

The soil texture was loamy sand (85\% sand, $11 \%$ silt and $4 \%$ clay) throughout the rootzone, with a $2.9 \% \mathrm{CaCO}_{3}$ content and a $\mathrm{pH}$ of 8.2. The soil $\mathrm{pH}$ has been increasing very slowly due to irrigation water. The soil was deep and well drained with no known impervious layer. The depth to the water table ranged from 50 to $80 \mathrm{~m}$. The trees were managed according to standard local commercial practices, pruned annually, and watered as needed using a drip-irrigation system delivering (120 to 180 ) L per day. The irrigation water had a $\mathrm{pH}$ of 8.0 and an electrical conductivity of $1.02 \mathrm{dS} \cdot \mathrm{m}^{-1}$. In early November, each tree was fertilized with $1.0 \mathrm{~kg}$ of $18-7.9-4.2-1.5$ (N-P-K-Mg) and $25 \mathrm{~kg}$ of composted manure. One kilogram of $\mathrm{N}$ from urea was also applied three times (1/2 in January, 1/4 in March and 1/4 in May). In the spring, foliar sprays of manganese and zinc were also applied. The soil was kept free of weeds using post-emergence herbicides. Pest populations were kept under control following a recommended pest management program. 
The fruit yield of each tree was taken at harvest. Fruit samples (10 fruits per tree from all canopy sides) from each experimental plot were collected for fruit quality measurements and evaluations. Individual fruit weight, fruit diameter, peel thickness, juice weight, total soluble solids or Brix, and titratable acid concentrations were determined in the laboratory using standard procedures. Juice was extracted from the fruit samples, weighed, and tested for Brix and acid. The Brix content (mostly soluble sugars) was determined using a hydrometer that measured the specific gravity, which was converted to degrees Brix. The percent acid was determined by titration using sodium hydroxide and a phenolphthalein indicator.

The experiment was a complete randomized block design and consisted of nine treatments (rootstocks) with four replications of 4-tree plots. Statistical analysis was conducted using analysis of variance and Duncan's multiple range test was used for mean comparison when the F-test was significant at $P<0.05$.

\section{Results and discussion}

\subsection{Fruit yield}

Overall, fruit yield was higher for Valencia than for Navel fruit (table I). Fruit yield was generally better in 1995 due to the relatively dry and cool winter weather, which induced heavier bloom and better fruit set compared with the other years. Over the seven-year production period, trees on Volkamer lemon, Citrus macrophylla and rough lemon were the most productive. Trees on Swingle citrumelo and Cleopatra mandarin were the least productive. Trees on sour orange, Carrizo citrange, Citrus taiwanica and Amblycarpa were intermediate in fruit production (table I). The poor crop for trees on Cleopatra mandarin was partly attributed to $P h y$ tophthora infestation, which also reduced growth and tree size. Trees on Cleopatra mandarin grew slowly and fruited poorly during the first few years. Trees on Swingle citrumelo had dieback, were relatively small, and consistently produced fewer fruit. This

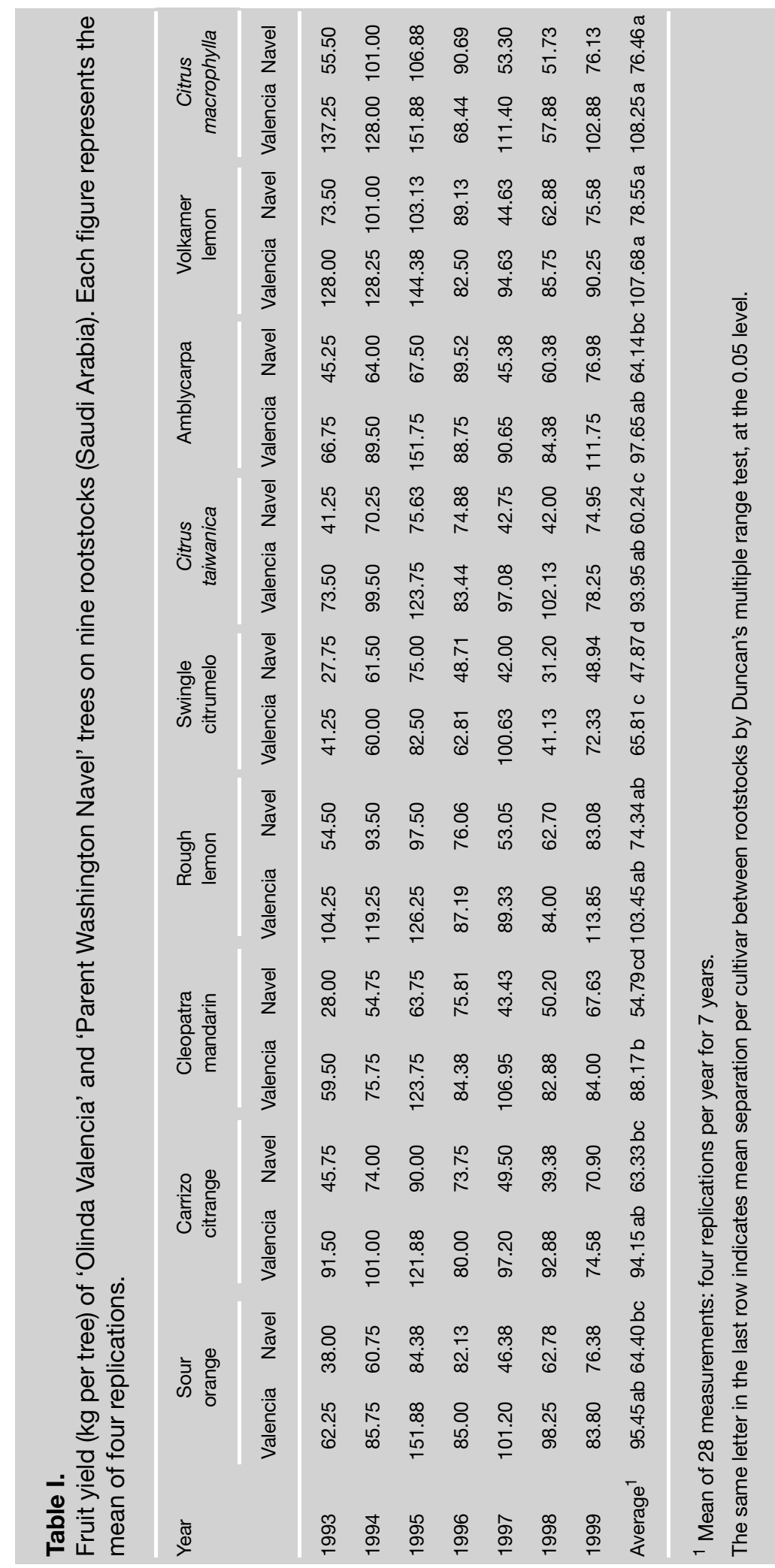


was also consistent with Gardner and Horanic [8] who concluded that scions on Cleopatra mandarin were not precocious. Similar results of yield problems for trees on Cleopatra mandarin have been found in many citrus areas in the world. Cleopatra mandarin is considered a "lazy" rootstock because trees grafted to it fruit relatively poorly until they are (10 to 15$)$ years of age [26].

The yield results of this study were consistent with results of several studies conducted in different citrus-growing regions where cumulative yields were higher on trees budded on Volkamer lemon and rough lemon than on those budded on Swingle citrumelo and Cleopatra mandarin [5, 12, 18, $25,27]$. However, in other studies, no significant differences in cumulative yields were found between rootstocks including Cleopatra mandarin, Sour orange, Carrizo citrange, Volkamer lemon, rough lemon, Citrus taiwanica and Citrus macrophylla [6, 11]. Furthermore, trees on Swingle citrumelo produced the highest fruit yield as compared with other rootstocks [14, 15, 17, 19, 20]. All these results indicate the inconsistency in yield differences as affected by rootstocks, which could be attributed to differences in scion cultivars, tree age, climatic conditions and soil characteristics.

\subsection{Fruit size}

The largest fruit were obtained from trees on Volkamer lemon, Citrus macrophylla and rough lemon, while the smallest fruit were found on trees budded on Cleopatra mandarin and Sour orange (table II). Similar results were found by several other authors, where fruit were the smallest or lightest from trees on Sour orange and Cleopatra mandarin and the largest or heaviest from trees on Volkamer lemon, rough lemon and Citrus macrophylla [3, 4, 12, 14, 19, 25]. On the other hand, no significant differences were found in 'Valencia' orange fruit size and weight between trees growing on rough lemon, Cleopatra mandarin, Sour orange and Citrus taiwanica [18], and 'Fairchild' fruit weight was higher from trees on Citrus taiwanica than fruit from trees on rough lemon, Carrizo citrange and Citrus macrophylla [7]. Furthermore, 'Ambersweet' orange 
fruit from trees on Cleopatra mandarin were found to be larger and heavier than those from trees on Swingle citrumelo, which could be attributed to the low number of fruit per tree on Cleopatra mandarin [21]. In general, fruit size is correlated with fruit number per tree. The fewer the fruit on the tree, the larger and heavier the fruit. Moreover, in a particular year, besides fruit load, the ultimate size a citrus fruit achieves is the result of many complex factors including nutrition and irrigation programs, rainfall distribution, pruning, and the rootstock/scion combination. Large fruit size is most often preferred in the fresh fruit market and brings high prices early in the season.

\subsection{Peel thickness}

Another determinant of citrus fresh quality is peel thickness, firmness or texture. Neither extreme in peel thickness is desirable. Fruit with thick peel are usually low in juice, while those with thin peel are prone to splitting and are sensitive to post-harvest problems that can occur during shipping and storage. Peel thickness was also affected by the rootstock. Peel thickness was the highest in fruit collected from Valencia on Citrus taiwanica and C. macrophylla and Navel on rough lemon and the lowest in fruit collected from Valencia on Cleopatra mandarin, Swingle citrumelo and Amblycarpa and Navel on Cleopatra mandarin and Sour orange (table III). Differences in fruit peel thickness as affected by rootstock have also been reported in some previous studies. Peel thickness of 'Orlando' tangelo was higher for trees on rough lemon [6] and that of grapefruit was higher on Citrus taiwanica [5] as compared with Carrizo citrange. Fruit rind thickness was found to be the highest for 'Marsh' grapefruit trees on Citrus taiwanica and Amblycarpa and the lowest for trees on Swingle citrumelo, Carrizo citrange and Estes rough lemon [4]. Trees on Sour orange and Volkamer lemon produced fruit with the thickest rind $[12,16]$. However, for 'Marrs' oranges, rind thickness was the highest from trees on Swingle citrumelo [19] and grapefruit rind thickness was higher for fruit from trees on Cleopatra mandarin than for those on Citrus taiwanica and rough lemon [17].

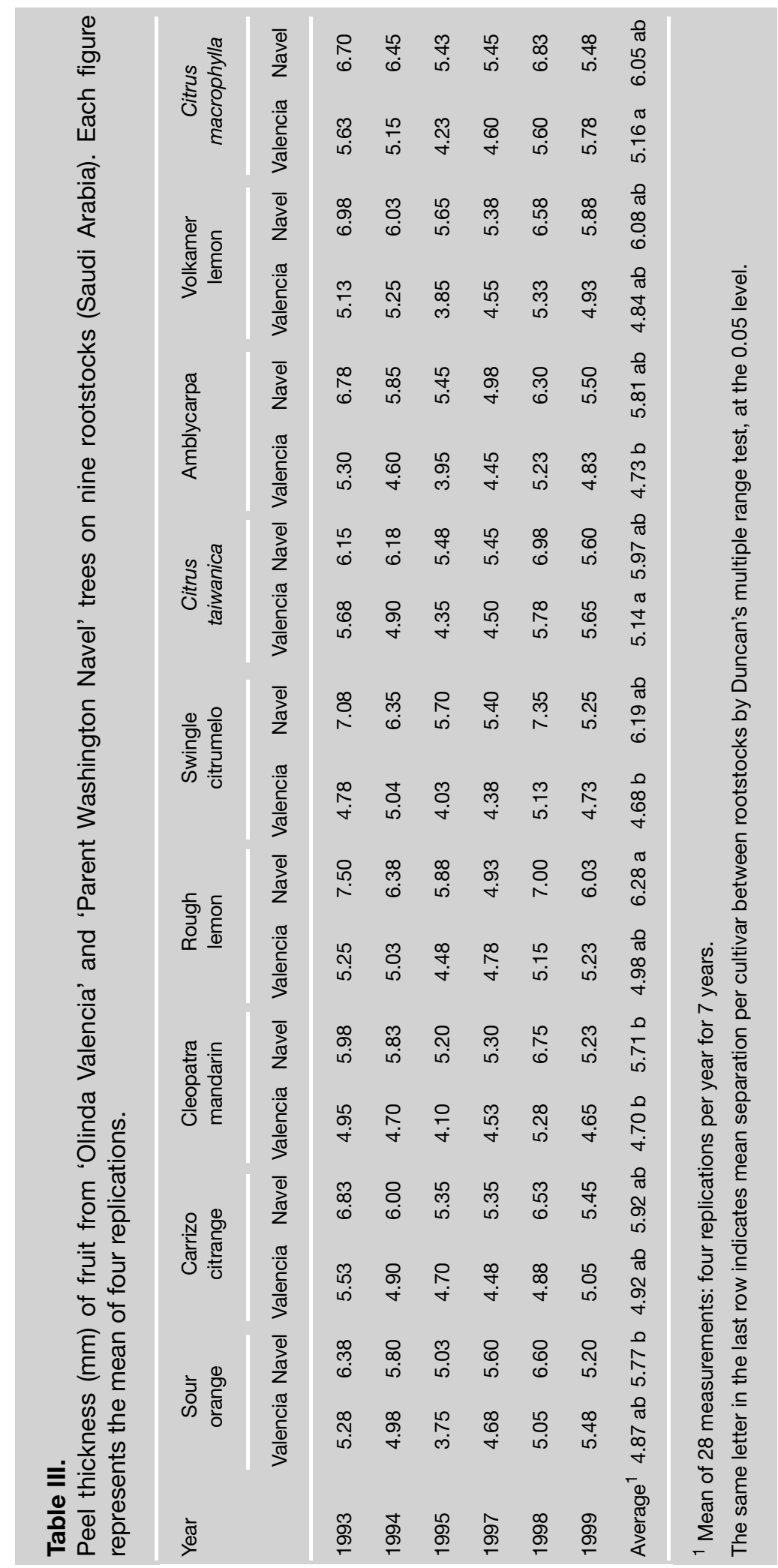


From all those studies, there is no consistent trend that the more vigorous rootstocks promoted thicker peel. Furthermore, not all rootstock studies showed differences in peel or rind thickness between rootstocks. Wutscher and Shull [19] did not find a significant difference in rind thickness of 'Orlando' tangelo fruit from trees grown on all the four rootstocks studied: Swingle citrumelo, Sour orange, Cleopatra mandarin and Citrus taiwanica.

\subsection{Juice content}

Overall, juice content was relatively higher for Valencia than for Navel fruit (table IV). The juicier the fruit, the better is its acceptance not only for the juice market but also as a fresh fruit. Juice content values were generally higher in 1995 . They might be attributed to differences in weather conditions and to the relatively lower peel thickness, particularly for Valencia. Like other fruit quality variables, juice content was affected by the rootstock and varied through the years. For Valencia, fruit from trees on Swingle citrumelo had the highest juice content while those from trees on Sour orange, rough lemon and Citrus taiwanica had the lowest juice content. On the other hand, fruit from Navel trees on Cleopatra mandarin had the highest juice content while those from trees on rough lemon had the lowest juice content (table IV). Similar results have been reported from some earlier studies. Fruit from trees on Swingle citrumelo and Cleopatra mandarin had the best juice percentage compared with trees on Volkamer lemon, Carrizo citrange and Sour orange [12]. Fruit from trees on Citrus taiwanica had the lowest percent of juice compared with rough lemon, Volkamer lemon, C. macrophylla and Carrizo citrange [5]. Fruit from trees on Carrizo citrange and rough lemon contained more juice than those from trees on C. macrophylla [6]. However, the juice content of 'Marrs' orange was the highest for trees on Sour orange and the lowest for trees on C. taiwanica [20]. In general, the larger the fruit and the thicker the peel or rind, the lower the juice content. Juice content was the highest for Sour orange and the lowest for Estes rough lemon, Volkamer lemon, Amblycarpa and Cleopatra mandarin [4], and 
'Hamlin' fruit from trees on rough lemon and Volkamer lemon had the lowest percent of juice [16]. On the other hand, not all rootstock studies demonstrated that rootstocks had an influence on juice content. For example, no significant difference in the juice content of 'Orlando' tangelo, 'Comune' Clementine, 'Fairchild' mandarin and grapefruit was found from trees grown on all the studied rootstocks [3, 7, 17, 19].

\subsection{Soluble solids}

The flavor and palatability of citrus fruits is a function of relative levels of soluble solids, acids, and the presence or absence of various aromatic or bitter juice constituents. Although fruit quality standards, which determine minimum levels of acceptability, have not been established in Saudi Arabia, soluble solids concentration in the juice has not been completely ignored as an important parameter for fresh fruit. Overall, soluble solids in the juice were higher for Valencia than for Navel fruit (table V). Rootstocks were also found to affect soluble solids concentration in fruit juice. Soluble solids concentration in fruit from trees on Carrizo citrange and Sour orange was the highest while it was the lowest for fruit from those on Citrus macrophylla, Citrus taiwanica, rough lemon and Volkamer lemon (table V). Similar results were obtained by other authors. Total soluble solids were the lowest for rough lemon and the highest for Cleopatra mandarin and Sour orange $[11,17]$. Total soluble solids were among the highest from fruit on Sour orange [12, 18, 20]. Fruit from trees on Sour orange, Carrizo citrange and/or Cleopatra mandarin had the highest soluble solids concentration, while those on Volkamer lemon and rough lemon had the lowest soluble solids concentration [3, 5, 7, 16, 27]. Total soluble solids were among the highest for fruit from trees on Swingle citrumelo and the lowest for fruit from trees on rough lemon, Volkamer lemon and Milam [4, 25]. The results on soluble solids of all these studies are consistent, showing poorer internal fruit quality for trees grown on relatively vigorous rootstocks such as rough lemon and Volkamer lemon compared with trees grown on less vigorous rootstocks such as Swingle citrumelo and Sour orange.

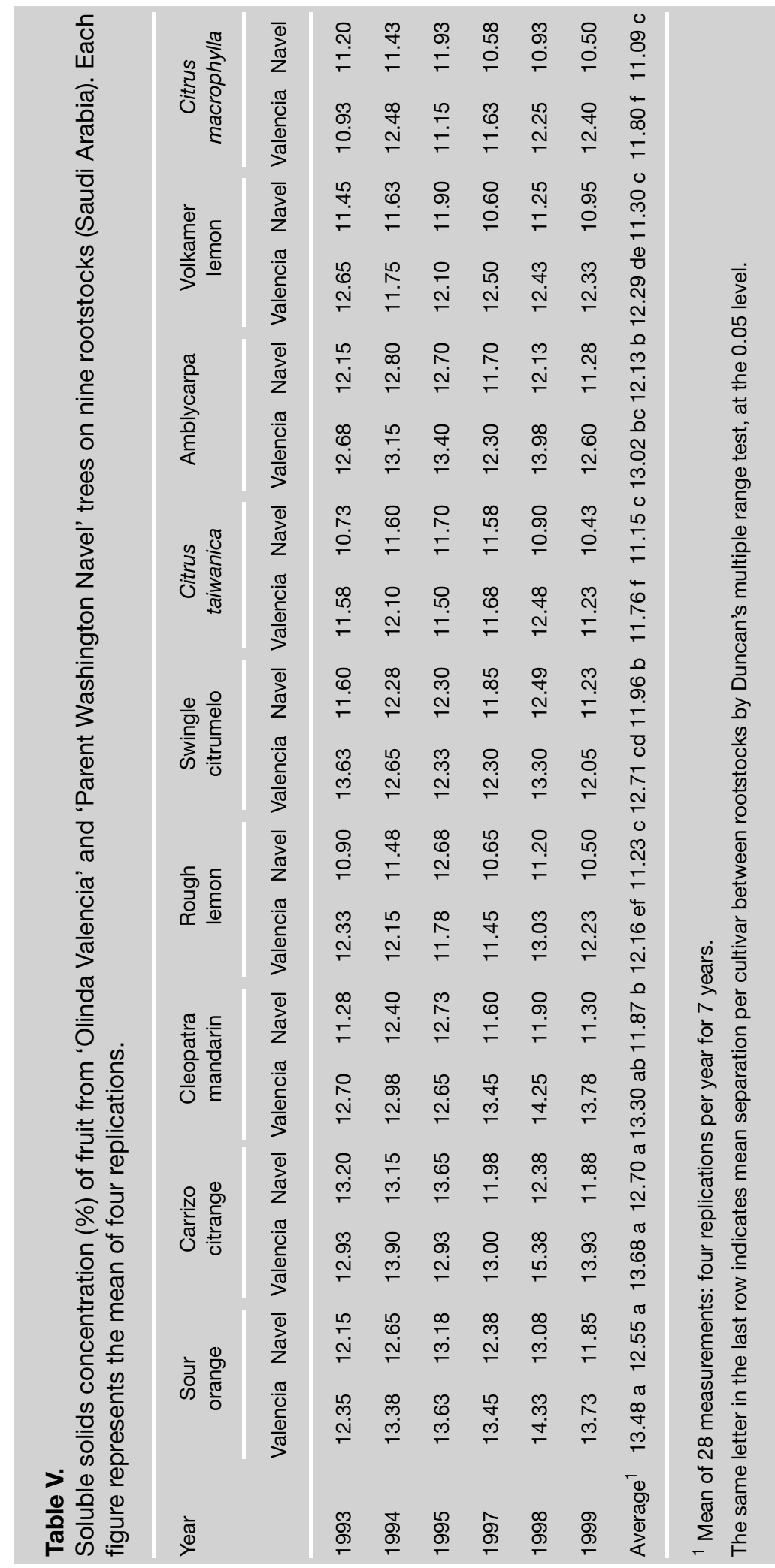




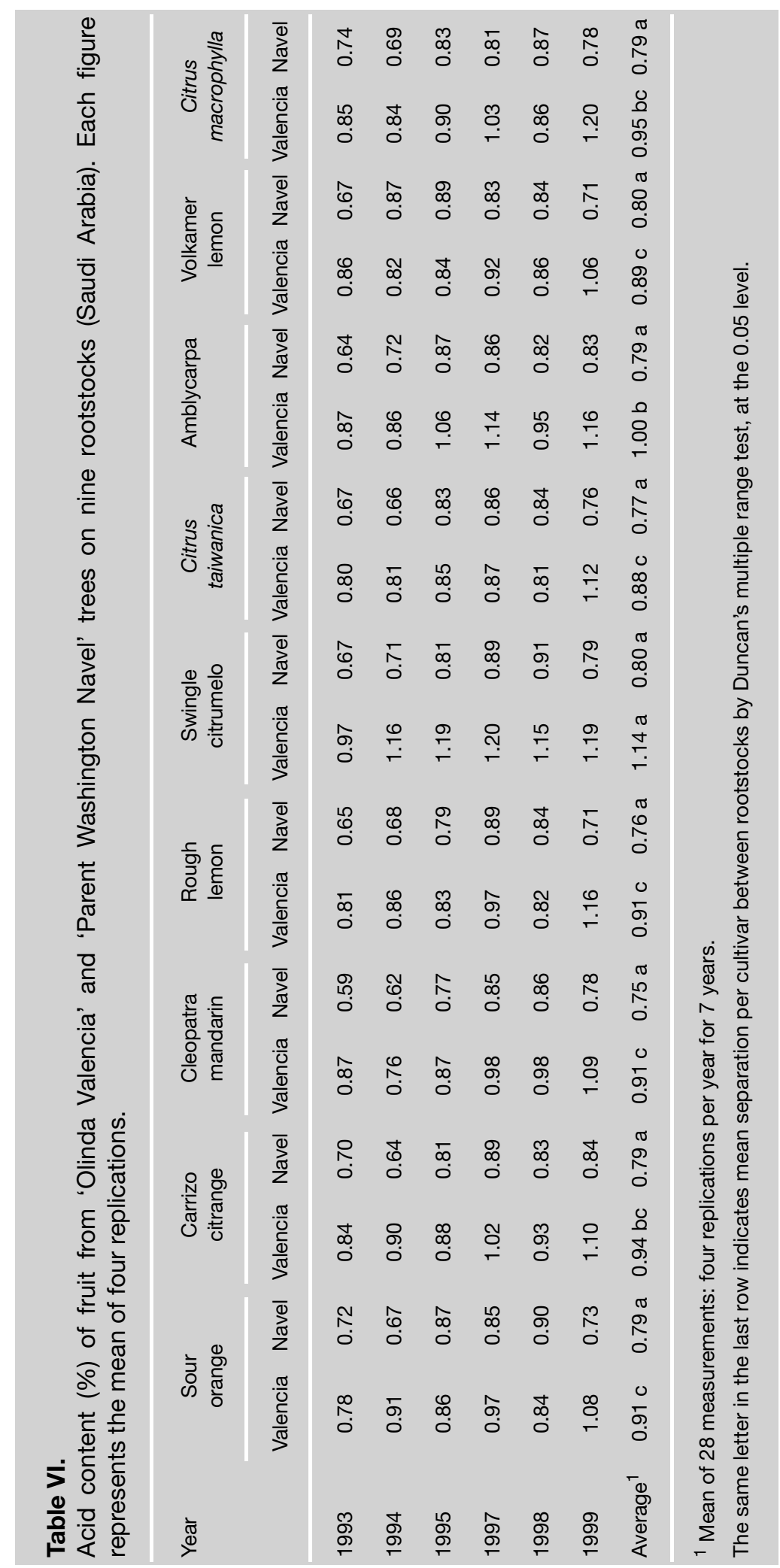

\subsection{Acid content}

Total acidity of citrus juices is an important factor in overall juice quality and in determining the time of harvest in several citrusproducing countries. In this study, for Navel, acid content in the juice was not affected by the rootstocks. However, acid content in the juice of fruit from Valencia trees on Swingle citrumelo and Amblycarpa was higher than that from trees on Sour orange, Cleopatra mandarin, rough lemon, C. taiwanica and Volkamer lemon (table VI). In several other studies, acid content in the juice differed between rootstocks. The lowest total acids in the fruit juice were from trees on C. taiwanica and the highest were from trees on Swingle citrumelo [19, 20]. Acid content was the highest for trees grown on Sour orange and the lowest for trees on Volkamer lemon and rough lemon [3]. Total acid was among the highest in the juice from trees on Carrizo citrange, Swingle citrumelo and Cleopatra mandarin and the lowest from trees on rough lemon and Volkamer lemon [5, 7, 16, 17]. Although internal fruit quality, including acid content, can be affected by the scion cultivar, tree age and other factors, the results on acid content from most of these studies are consistent, showing relatively low acid content for trees grown on lemon rootstocks.

\section{Conclusions}

Rootstocks can affect the success and profitability of virtually any commercial citrus culture. Rootstock use is considered essential in citriculture because of its strong influence on how and where citrus can be grown successfully. In this study, it was quite obvious that the rootstocks had a significant effect on fruit yield and quality. Failure to assess accurately the impact of climate, soils and rootstocks on the economic profitability of citrus can be a major reason for crop losses or reduced income because of reduced yield and quality potential. Trees on C. macrophylla, Volkamer lemon and rough lemon rootstocks were more vigorous, precocious and more productive than those on the other rootstocks. Cleopatra 
mandarin and Swingle citrumelo rootstocks are not recommended for the Najran area of Saudi Arabia because of Cleopatra mandarin's high susceptibility to Phytophthora, particularly in over-watered areas and poorlydrained situations, and because of Swingle citrumelo's poor adaptability to high $\mathrm{pH}$ soil, calcareous soils, and/or a relatively saline environment. Valencia trees were more profitable than Navel trees, producing more fruit with higher juice content and soluble solids. Based on this study, C. macrophylla, Volkamer lemon and rough lemon are good choices as rootstocks for 'Olinda Valencia' and 'Parent Washington Navel' orange in the Najran area of Saudi Arabia.

\section{References}

[1] Zekri M., Al-Jaleel A., The citrus industry in Saudi Arabia, Citrus Ind. Mag. 81 (11) (2000) 24-26.

[2] Al-Jaleel A., Zekri M., Yield and fruit quality of 'Olinda Valencia' trees grown on nine rootstocks in Saudi Arabia, Proc. Fla. State Hortic. Soc. 115 (2002) 17-22.

[3] Continella G., Germana C., La Rosa G., Tribulato E., Performance and physiological parameters of 'Comune' clementine influenced by four rootstocks, in: Goren R., Mendel K. (Eds.), Proc. Sixth Inter. Citrus Congr., Margraf, Weikersheim, Germany, 1989, pp. 91-100.

[4] Economides C.V., Gregoriou C., Growth, yield, and fruit quality of nucellar frost 'Marsh' grapefruit on fifteen rootstocks in Cyprus, J. Am. Soc. Hortic. Sci. 118 (3) (1993) 326-329.

[5] Fallahi E., Moon Jr. J.W., Rodney D.R., Yield and quality of 'Redblush' grapefruit on twelve rootstocks, J. Am. Soc. Hortic. Sci. 114 (2) (1989) 187-190.

[6] Fallahi E., Mousavi Z., Rodney D.R., Performance of 'Orlando' trees on ten rootstocks in Arizona, J. Am. Soc. Hortic. Sci. 116 (1) (1991) 2-5.

[7] Fallahi E., Rodney D.R., Tree size, yield, fruit quality, and leaf mineral nutrient concentration of 'Fairchild' mandarin on six rootstocks, J. Am. Soc. Hortic. Sci. 117 (1) (1992) 28-31.
[8] Gardner F.E., Horanic G.E., A comparative evaluation of rootstocks for Valencia and Parson Brown oranges on Lakeland fine sand, Proc. Fla. State Hortic. Soc. 74 (1961) 123-127.

[9] Gardner F.E., Horanic G.E., Growth, yield, and fruit quality of Marsh grapefruit on various rootstocks on the Florida East Coast - A preliminary report, Proc. Fla. State Hortic. Soc. 79 (1966) 109-114.

[10] Grisoni M., Cabeu P., Aubert B., Résultats de douze années d'un essai de comportement de cinq porte-greffes en association avec quatre cultivars d'agrumes à l'île de la Réunion, Fruits 44 (10) (1989) 529-537.

[11] Hearn C.J., Yield and fruit quality of 'Ambersweet' orange hybrid on different rootstocks, Proc. Fla. State Hortic. Soc. 102 (1989) 75-78.

[12] Monteverde E.E., Reyes F.J., Laborem G., Ruiz J.R., Citrus rootstocks in Venezuela: behavior of Valencia orange on ten rootstocks, in: Goren R., Mendel K. (Eds.), Proc. Sixth Inter. Citrus Congr., Margraf, Weikersheim, Germany, 1989, pp. 47-55.

[13] Roose M.L., Cole D.A., Atkin D., Kupper R.S., Yield and tree size of four citrus cultivars on 21 rootstocks in California, J. Am. Soc. Hortic. Sci. 114 (4) (1989) 678-684.

[14] Rouse R.E., Maxwell N.P., Performance of mature nucellar 'Redblush' grapefruit on 22 rootstocks in Texas, J. Am. Soc. Hortic. Sci. 104 (4) (1979) 449-451.

[15] Wheaton T.A., Castle W.S., Whitney J.D., Tucker D.P.H., Performance of citrus scion cultivars and rootstocks in a high-density planting, HortScience 26 (7) (1991) 837-840.

[16] Wutscher H.K., Bistline F.W., Performance of 'Hamlin' orange on 30 citrus rootstocks in southern Florida, J. Am. Soc. Hortic. Sci. 113 (4) (1988) 493-497.

[17] Wutscher H.K., Maxwell N.P., Shull A.V., Performance of nucellar grapefruit, Citrus paradisi Macf., on 13 rootstocks in south Texas, J. Am. Soc. Hortic. Sci. 100 (1) (1975) 48-51.

[18] Wutscher H.K., Shull A.V., The performance of Valencia orange trees on 16 rootstocks in south Texas, Proc. Trop. Reg. Am. Soc. Hortic. Sci. 17 (1973) 66-73.

[19] Wutscher H.K., Shull A.V., Performance of 'Orlando' tangelo on 16 rootstocks, J. Am. Soc. Hortic. Sci. 101 (1) (1976) 88-91. 
[20] Wutscher H.K., Shull A.V., Performance of 'Marrs' early orange on eleven rootstocks in south Texas, J. Am. Soc. Hortic. Sci. 101 (2) (1976) 158-161.

[21] Zekri M., Leaf mineral concentration, growth, yield, fruit quality, and economics of 'Ambersweet' orange trees on two rootstocks, Proc. Fla. State Hortic. Soc. 109 (1996) 92-96.

[22] Zekri M., Performance of 'Ambersweet', a new citrus hybrid cultivar, on two rootstocks in Florida, Fruits 52 (3) (1997) 141-148.

[23] Zekri M., Performance of 'Valencia' orange trees on four rootstocks in a high-density planting, Proc. Interam. Soc. Trop. Hortic. 43 (1999) 108-115.
[24] Zekri M., Citrus rootstocks affect scion nutrition, fruit quality, growth, yield and economical return, Fruits 55 (4) (2000) 231-239.

[25] Zekri M., Evaluation of orange trees budded on several rootstocks and planted at high density on flatwoods soil, Proc. Fla. State Hortic. Soc. 113 (2000) 119-123.

[26] Castle W.S., Tucker D.P.H., Krezdorn A.H., Youtsey C.O., Rootstocks for Florida citrus, Univ. Florida, SP 42, USA, 1993.

[27] Castle W.S., Wutscher H.K., Youtsey C.O., Pelosi R.R., Citrumelos as rootstocks for Florida citrus, Proc. Fla. State Hortic. Soc. 101 (1988) 28-33.

\section{Evaluación de patrones para naranjos Valencia y Navel en Arabia Saudita.}

Resumen - Introducción. Las condiciones medioambientales y las prácticas de cultivo varían considerablemente de una región a otra. Por esta razón, se efectuó un estudio a largo plazo para estudiar la adaptabilidad y el desempeño hortícola de naranjos de tipo Washington Navel y Valencia Olinda sobre nueve patrones comerciales en la región de Najran en Arabia Saudita. Material y métodos. Los árboles se plantaron en 1987 a $(6,0 \times 6,0) \mathrm{m}$ de intervalo y con una densidad de 278 árboles ha $^{-1}$. Se midió el rendimiento de frutos, el tamaño y el peso individual del fruto, el grosor de la piel, el porcentaje de jugo, el extracto seco y la acidez. Resultados. Tras un período de producción de 7 años, los árboles injertados sobre Citrus volkameriana (VL), C. macrophylla ( $\mathrm{Cm}$ ) y Rough lemon (RL) fueron los más productivos y los injertados sobre mandarina Cleopatra (Cleo) y citrumelo Swingle (Sc) fueron los menos productivos. Los árboles injertados sobre naranja amarga (SO), Amblicarpa, citrange Carrizo (CC) y C. taiwanica $(C t)$ tuvieron una producción intermedia. El mayor peso individual del fruto y los frutos con mayor tamaño se localizaron en los árboles injertados sobre RL, VL o $\mathrm{Cm}$, mientras que el peso del fruto más bajo y los frutos más pequeños se localizaron en los árboles injertados sobre Cleo y SO. Los naranjos injertados sobre RL presentaron el contenido de jugo más bajo. Los frutos de los árboles injertados sobre CC y SO tuvieron las tasas más altas de sólidos solubles mientras que los frutos sobre $C m$ y $C t$ tuvieron las más bajas. Los naranjos Valencia produjeron más frutos, con más jugo y sólidos solubles que los naranjos Navel. Conclusión. Generalmente, los árboles sobre citrumelo Swingle y mandarina Cleopatra fueron los menos productivos. Los árboles sobre patrones vigorosos (C. volkameriana, C. macrophylla, rough lemon) presentaron mejores resultados y fueron más productivos que los naranjos injertados sobre otros patrones; los naranjos Valencia se mostraron más interesantes que los Navel.

Arabia Saudita / Citrus sinensis / portainjertos / ensayos de variedades / desempeño de cultivos 